\title{
Helicobacter pylori Virulence Factor Cytotoxin-Associated Gene A (CagA)-Mediated Gastric Pathogenicity
}

\author{
Shamshul Ansari ${ }^{1}$ (1) and Yoshio Yamaoka ${ }^{2,3,4,5, *(1)}$ \\ 1 Department of Microbiology, Chitwan Medical College, Bharatpur 44200, Nepal; \\ ansari.shamshul@cmc.edu.np \\ 2 Department of Environmental and Preventive Medicine, Oita University Faculty of Medicine, \\ Yufu, Oita 879-5593, Japan \\ 3 Global Oita Medical Advanced Research Center for Health (GO-MARCH), Yufu, Oita 879-5593, Japan \\ 4 Department of Medicine, Gastroenterology and Hepatology Section, Baylor College of Medicine, \\ Houston, TX 77030, USA \\ 5 Borneo Medical and Health Research Centre, Universiti Malaysia Sabah, Kota Kinabalu, \\ Sabah 88400, Malaysia \\ * Correspondence: yyamaoka@oita-u.ac.jp; Tel.: +81-97-586-5740; Fax: +81-97-586-5749
}

Received: 21 September 2020; Accepted: 6 October 2020; Published: 8 October 2020

check for updates

\begin{abstract}
Helicobacter pylori causes persistent infection in the gastric epithelium of more than half of the world's population, leading to the development of severe complications such as peptic ulcer diseases, gastric cancer, and gastric mucosa-associated lymphoid tissue (MALT) lymphoma. Several virulence factors, including cytotoxin-associated gene A ( $\mathrm{Cag} A)$, which is translocated into the gastric epithelium via the type 4 secretory system (T4SS), have been indicated to play a vital role in disease development. Although infection with strains harboring the East Asian type of CagA possessing the EPIYA-A, - B, and -D sequences has been found to potentiate cell proliferation and disease pathogenicity, the exact mechanism of CagA involvement in disease severity still remains to be elucidated. Therefore, we discuss the possible role of CagA in gastric pathogenicity.
\end{abstract}

Keywords: H. pylori; virulence factor; cag pathogenicity island; CagA; gastric cancer

\section{Introduction}

Helicobacter pylori is the most common bacterium, which colonizes the gastric epithelium of more than $50 \%$ of the world's population [1,2]. Geographic variation, socio-economic status, urbanization level, and poor sanitation during childhood have been found to affect the infection prevalence variation between countries, with the highest prevalence in Asian, Middle American, and South American countries [2,3]. The global prevalence has been estimated to be $44.3 \%$, whereas the highest prevalence of $89.7 \%$ and the lowest prevalence of $8.9 \%$ have been found in Nigeria and Yemen, respectively [1].

Although the exact route of transmission of $H$. pylori is still unclear, the epidemiological evidence supports its oral-oral or fecal-oral transmission from person to person, particularly among those in close contact, such as between mother and child, with a greater chance of infection transmission in childhood [4-6]. Yokota et al. conducted a study using multi-locus sequence typing and random amplified polymorphic DNA fingerprinting, and they revealed that the transmission of $H$. pylori occurs from mother to child after the first year of life [7]. Once H. pylori is transmitted to the gastric lumen, a permanent infection is established in the stomach, and if left untreated, leads to several 
gastro-duodenal conditions such as chronic gastritis, gastric ulcer, duodenal ulcer, gastric cancer, and gastric mucosa-associated lymphoid tissue (MALT) lymphoma $[8,9]$.

A vigorous immune response causing inflammation in the gastric mucosa is observed, and the inability to eradicate the organism from the stomach where it leads to persistent infection plays a decisive role in the development of gastric cancer [10]. However, it is a long-term process that takes several decades and is influenced by the gastric environment, host factors, and bacterial virulence factors, resulting in the development of gastric complications such as peptic ulcer disease and gastric cancer [11]. Several $H$. pylori virulence factors that have been estimated to contribute to the pathogenicity and development of gastric cancer are vacuolating cytotoxin A (VacA) (Reviewed by Ansari and Yamaoka [12]), cytotoxin-associated gene pathogenicity island (cagPAI), an oncoprotein (i.e., cytotoxin-associated gene A (CagA)), and adhesion proteins [13]. This review was conducted to compile the latest findings regarding $\mathrm{CagA}$ and its association with gastric complications development to give a concise report on different aspects of this protein such as its synthesis, transportation, and effector functions. A PubMed search was conducted using the key words "pylori" and "CagA" together or in combination with one more key word such as "pathogenicity," "gastric complications," or "gastric cancer." Among the results, we considered the full-text articles published in English in 2015 or later. However, for greater clarity and deeper insight, we also considered a few older articles. Abstracts, case reports, editorials, commentaries, or manuscripts published in languages other than English were excluded.

\section{Cytotoxin-Associated Gene Pathogenicity Island (cagPAI)}

Nearly $70 \%$ of all $\mathrm{H}$. pylori strains isolated worldwide have been found to possess cagPAI, compared with $95 \%$ of East-Asian isolates and $60 \%$ of western isolates [13,14]. cagPAI is comprised of approximately $40 \mathrm{~kb}$ of chromosomal DNA consisting of up to 32 open reading frames (ORFs), namely cag 1 to $c a g 26, \operatorname{cag} A$ to $c a g Z$, or cag $\alpha$ to cag $\zeta$, or by locus name of the HP 26,695 or HP J99 strain genomes [15] that encode effector protein CagA and components of the bacterial type IV secretion system (T4SS), which forms a syringe-like structure to deliver CagA into gastric epithelial cells [16,17]. However, at least 17 genes of cagPAI must be expressed to encode intact T4SS with its essential functions, and 14 genes must be expressed to fully induce interleukin-8 (IL-8) secretion [16,18]. It has been suggested that intact T4SS consists of a core complex comprised of CagT, CagX, CagM, Cag $\delta$, and CagY, with associated factors $\mathrm{CagH}, \mathrm{CagN}$, $\mathrm{CagU}$, CagV, and $\mathrm{CagW}$; pilus components CagC, CagH, CagI, $\mathrm{CagL}$, and $\mathrm{Cag} Y$; and energetic components $\mathrm{CagE}$, $\mathrm{Cag} \alpha$, and $\mathrm{Cag} \beta$. In addition, $\mathrm{CagF}, \mathrm{CagZ}$, and $\mathrm{Cag} \beta$ act as translocation-associated factors, whereas $\mathrm{Cag} \gamma$ acts as a lytic trans-glycosylase [16], as shown in Figure 1. Inactivation of some of these essential genes has been found to result in a nonfunctional T4SS in strains, rendering no CagA-mediated pathogenicity, which behave like cagPAI, completely absent [19-21]. Although cagPAI integrity is critical to encode intact T4SS for the interaction of H. pylori with the host cells, not all strains contain a cagPAI, and in some strains, it is incomplete $[19,20]$. The development of severe gastric complications, such as chronic gastritis, peptic ulcer diseases, and gastric cancer, has been associated with infection with strains expressing the intact cagPAI [13,22].

A higher risk of gastric cancer or peptic ulcer disease development has been found in individuals infected with strains harboring cagPAI compared with individuals infected with cagPAI-negative H. pylori strains [13,23]. In a recent study conducted in 263 patients in Alaska, the presence of intact cagPAI was detected in $150(57 \%)$ of $H$. pylori strains that were found to be associated with the development of more severe gastric pathology. Out of $12 \mathrm{H}$. pylori strains isolated from gastric cancer patients, $10(83 \%)$ had intact cagPAI, whereas 2 strains $(17 \%)$ had partially deleted cagPAI, and the complete absence of cagPAI was not found in any of the gastric cancer strains [24]. Similarly, another study conducted in Bulgaria that recruited 156 patients also found the presence of intact cagPAI in $100(64.1 \%)$ isolates. In the study, out of 33 strains recovered from peptic ulcer disease (PUD) patients, $29(88 \%)$ isolates had intact cagPAI, only $4(12 \%)$ isolates were found to have partially deleted cagPAI, and none had completely deleted cagPAI genes [25]. 


\begin{tabular}{|c|c|c|c|c|c|c|c|c|c|c|c|c|c|c|c|c|c|c|c|c|c|c|}
\hline Cag & 3 & & $\delta$ & $\forall F$ & $\alpha$ & z & $\begin{array}{r}Y \\
X\end{array}$ & $\mathbf{w}$ & v & $\begin{array}{l}U \\
\end{array}$ & $s$ & Q P & M & $\mathbf{N}$ & L & $1 \mathrm{H}$ & $\begin{array}{r}H \quad G \\
\end{array}$ & $\mathrm{~F}$ & $\mathrm{E}$ & & B & $A$ \\
\hline Functions & & & & & & & & & & & & & & & & & & & & & & \\
\hline Core complex & & & $\bullet$ & & & & - $\bullet$ & $\bullet$ & - & - $\bullet$ & & & $\bullet$ & $\bullet$ & & & & & & & & \\
\hline Pilus components & & & & & & & & & & & & & & & $\bullet$ & $\bullet \bullet$ & $\bullet$ & & & - & • & \\
\hline Energy components & & & & $\bullet$ & - & & & & & & & & & & & & & & $\bullet$ & & & \\
\hline $\begin{array}{l}\text { Translocation-associated } \\
\text { factors }\end{array}$ & & & & & & $\bullet$ & & & & & & & & & & & & $\bullet$ & & & & \\
\hline Lytic tranglycosylase & & & & & & & & & & & & & & & & & & & & & & \\
\hline $\begin{array}{l}\text { Translocated effector } \\
\text { protein }\end{array}$ & & & & & & & & & & & & & & & & & & & & & & - \\
\hline Accessory factor & & & & & & & & & & & & & & & & & $\bullet$ & & & $\bullet$ & & \\
\hline Nonessential factor & - & - & & & & & & & & & - & $\bullet \bullet$ & & & & & & & & & & \\
\hline Unknown & & & & & & & & & & & & & & & & & & & & & • & \\
\hline
\end{tabular}

Figure 1. Function of different Cag proteins. The respective function of the Cag protein component is shown by a black circle $[16,18]$.

\section{Cytotoxin-Associated Gene A (CagA)}

CagA is a $125-145 \mathrm{kDa}$ effector protein, and the strains expressing this protein are considered highly virulent strains, whereas the strains that lack this protein are less virulent cagPAI-negative strains [20]. After its synthesis, CagA is translocated into the gastric epithelial cells via T4SS. However, a relatively low amount of it is translocated inside the host epithelial cells despite its abundant synthesis [26].

CagA consists of a well-characterized motif comprising five amino acids, i.e., EPIYA (glutamic acid-proline-isoleucine-tyrosine-alanine), forming a sequence at the C-terminal region, which, together with the neighboring sequence, is responsible for the biological activity of CagA [13]. Depending on the geographic variation, $H$. pylori strains can possess four different types of EPIYA-sequences, i.e., EPIYA-A, -B, -C, and -D. The strains isolated from western countries usually possess CagA with EPIYA-A, $-\mathrm{B}$, and -C (one to three EPIYA-C regions), whereas strains from East Asian countries possess EPIYA-A, $-B$, and -D sequences. Almost all CagA strains possess the first two EPIYA-sequences, i.e., EPIYA-A and EPIYA-B, whereas the type and presence of the third EPIYA sequence depends on geographic, genotypic, and virulence characteristics, i.e., the EPIYA-C sequence is mostly found in CagA isolated from H. pylori in western countries, and the EPIYA-D sequence is mostly from East Asian H. pylori [27]. CagA with the EPIYA-D sequence has a higher capability of deregulation of cellular processes than CagA with the EPIYA-C sequence. Therefore, the strains possessing CagA with the first two EPIYA-sequences (EPIYA-A and EPIYA-B) together with the EPIYA-D sequence are considered more virulent than the strains possessing EPIYA-A, EPIYA-B, and EPIYA-C sequences [27]. Studies have also reported an increasing level of virulence with an increasing number of EPIYA-C sequences. A recent meta-analysis found a 1.91-fold increased risk for gastric cancer development associated with the presence of a single EPIYA-D sequence (EPIYA-A, -B, $-D$ ) in Asian countries compared with the presence of a single EPIYA-C sequence (EPIYA-A, $-B,-C$ ), and the presence of CagA with two or more EPIYA-C sequences (EPIYA-A, $-\mathrm{B},-\mathrm{C},-\mathrm{C}$ or EPIYA-A, $-\mathrm{B}$, $-C,-C,-C)$ was associated with a significant increase in the risk for PUD in Asian countries, while a 3.28-fold increased risk was observed for gastric cancer in the USA and Europe [28]. Despite the role of such neighboring sequences of EPIYA-motifs, the amino acid variation in the EPIYA-B tyrosine phosphorylation motif itself has been found to reduce the risk of developing severe complications. It was found that the strains with amino acid polymorphisms within the western-specific EPIYA-B motif, such as EPIYT-B, were found to influence the CagA activity, which reduces the ability to induce 
the hummingbird phenotype and IL-8 expression, conferring a high risk for duodenal ulcer but a lower risk for gastric cancer development [29].

Several polymorphisms in CagA other than the EPIYA-motifs have been associated with the development of gastric complications. In a recent study, polymorphisms on the nucleotide level in cagA, such as cagA1283 and cagA2551, have been associated with high-grade premalignant lesions, and the polymorphisms such as cagA2419 and cagA3435 together with polymorphism in cagL, such as cagL400, have been associated with the risk of gastric cancer development [30]. Moreover, amino acid variations in CagA such as V52I, S194F, and Q/R427K have been associated with the risk of intestinal metaplasia, whereas N467G has been associated with the development of gastric cancer [31]. The studies have found the development of gastric cancer only in 1-2\% of $H$. pylori-infected individuals and MALT lymphoma in even less than $0.1 \%$ of individuals [32,33]. Translocation of CagA has also been indicated in human B-lymphocytes, leading to the inhibition of apoptosis and continuous proliferation of B-lymphoid cells $[34,35]$. However, the detailed mechanisms of CagA-mediated pathogenicity still remain unknown. In a recent study, we reported the dominant presence of asparagine $(\mathrm{N})$, serine $(\mathrm{S})$, valine (V), and serine (S) at CagA site 314, 594, 684, and 1077, respectively, in strains isolated from gastric cancer when compared with the presence of amino acids in strain 26695, whereas serine (S), leucine $(\mathrm{L})$, valine $(\mathrm{V})$, and threonine $(\mathrm{T})$ were in the majority of strains isolated from MALT lymphoma patients [36].

\section{CagA Expression}

The pathogenicity of CagA protein results in disturbances in cellular signaling, and the expression of CagA increases gastric cancer risk [37,38]. It was previously shown that a variation in steady-state levels of CagA is found among H. pylori strains, modulated by its expression level $[39,40]$. The expression of CagA is affected by the specific motif. In another study, a high level of CagA expression associated with the strain-specific motif downstream of the cagA transcriptional start site (the +59 motif) was found in some strains but not in others $[30,40]$. This motif (the +59 motif) also stimulated the expression of higher levels of IL-8 production in cultured gastric cells, whereas expression was lower in strains lacking this motif [40]. A recent study reported the significance of this motif together with the neighboring structure. In the study, the +59 AATAAG motif and the adjacent stem-loop structure (stem-loop B) in the $c a g A 5^{\prime}$ untranslated region were found to play an important role in influencing the levels of cagA expression [41].

\section{CagA Translocation}

CagA, after its synthesis by H. pylori strains, is translocated into the gastric epithelial cells, and at least 15 cagPAI-encoded proteins are involved in forming T4SS [16,18], a syringe-like structure (Figure 2). The ultrastructural cytochemical data of a recent in vivo study conducted by Necchi et al., also support the direct translocation of CagA into the gastric epithelial cells by $\mathrm{H}$. pylori strains adhered on the lateral plasma membrane [42]. According to a recent study, the protease, i.e., high-temperature requirement protein A (HtrA), produced by H. pylori digests the E-cadherin, which acts as the cell adhesion molecule with the adjacent epithelial cells. This disruption enables the bacteria to penetrate the space between the epithelial cells and colonize the basolateral surfaces of the gastric cells [43]. The colonizing H. pylori bacteria at the basolateral surfaces have been found to express T4SS in higher numbers than those colonizing the apical surfaces. More than $70 \%$ of the $H$. pylori colonizing the basolateral surfaces were found to exhibit the T4SS pili, whereas a majority of the strains colonizing the apical surfaces exhibited no T4SS pili at all or few with only one pilus. This finding suggested the increased capability of $H$. pylori to express the T4SS system apparatus when colonizing the integrin-rich basolateral surfaces compared with H. pylori colonizing the apical surface [43]. CagA is exposed on the bacterial surface via T4SS and interacts with the phosphatidylserine (PS) patches that are aberrantly externalized because of the H. pylori infection and found on the plasma membrane of the host cells. The N-terminal region of the CagA has been found to interact with the PS patches, and the bound CagA is flipped inside, 
rendering the internalization of the CagA [44]. However, the translocation of CagA mediated by T4SS across the host cell membrane depends on a number of bacterial as well as host co-factors. The findings of a recent study showed that $\mathrm{CagV}$ is closely associated with the surface localization of CagA and its translocation across the host plasma membrane [45].

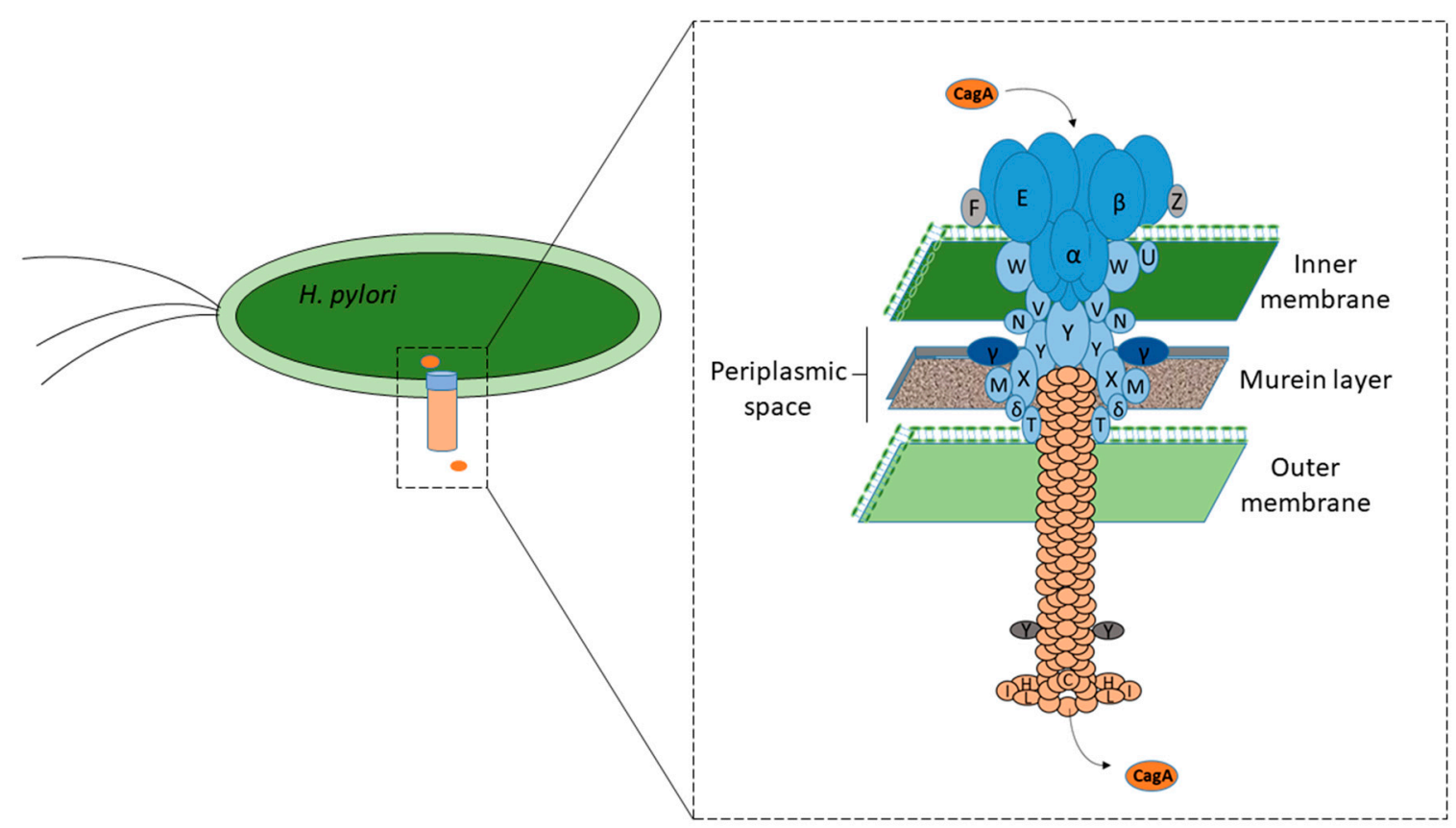

Figure 2. CagA after its synthesis is translocated into the gastric epithelial cells via T4SS, which forms a syringe-like structure $[16,18]$. The functions of various Cag proteins have been described in Figure 1.

CagL is a pilin-like component of T4SS encoded by the cagL gene (HP0539), which binds with human integrin $\beta 1$-containing receptors, such as integrin $\alpha 5 \beta 1[16,46]$. This integrin binding has been found to be mediated by a tripeptide motif of CagL, i.e., arginine-glycine-aspartic acid (RGD) at residues 76-78, together with the RGD helper sequence, which is a neighboring surface-exposed FEANE (phenylalanine-glutamic acid-alanine-asparagine-glutamic acid) motif [47]. In addition to its importance in the translocation of CagA, the RGD-dependent binding of CagL to integrins has also been found to trigger the intracellular signaling pathways that induce the CagA translocation-independent cell pro-inflammatory response [48-50]. The particular polymorphisms in CagL have also been associated with severe disease development, indicating its role in the translocation of CagA. In a study, particular polymorphisms upstream of the RGD motif at amino acid residues 58-62, called the CagL hypervariable motif (CagLHM), were correlated with severe disease progression in a geographically dependent manner [51,52]. Recently, studies have also found CagL polymorphisms such as D58, K59, M60, E62, K122, and I134 and novel CagL variants, and shown their association with chronic gastritis and PUD [53,54].

CagT, another T4SS component, has been found to be essential for T4SS activity [55-58]. The bacterial lipoproteins have been depicted to play a diverse role in the bacterial cell physiology, antimicrobial resistance, and pathogenicity. CagT undergoes $\mathrm{N}$-terminal modification consistent with lipidation and is required for the delivery of the H. pylori oncoprotein, i.e., CagA, into human gastric cells [59]. The lipidation of CagT is necessary for CagT stability, and thus, T4SS activity plays an important role in CagA translocation.

CagY has been elucidated to play an important role in T4SS functionality and, thus, disease severity $[58,60,61]$. A specific region of the cagY gene encodes a part of the CagY protein, which has been found to be an important component in epithelial cell binding [62]. A finding of a recent study also supports its role in the translocation of CagA [63]. In the study, the isolates recovered from 
$\alpha$-difluoromethylornithine (DFMO)-treated gerbils harbored the mutated cag $Y$ that exhibited a reduced ability to translocate CagA by T4SS. In addition, CagY has been elucidated to act as a regulator for immune-sensitive molecules that regulate the immune response to promote bacterial persistence and T4SS function $[48,64]$. Cag $\zeta$ (Cag1) has been found to be closely associated with the activity of T4SS, CagA translocation, and IL-8 expression [65]. CagQ, which is a membrane protein in T4SS, plays a key role for maintaining CagA expression and CagA-induced apoptotic effects [66]. CagE protein has been found to induce IL-8 secretion, mediating the host cell cytokine rearrangement in infected cells [57]. Moreover, the results of another recent study have indicated the role of CagX, CagY, CagM, CagT, and Cag 3 as an outer membrane complex that anchors the outer membrane of $H$. pylori and plays an essential role in the translocation of CagA [58].

Furthermore, the results of several other studies have suggested the important role of carcinoembryonic antigen-related cell adhesion molecule (CEACAM) receptors binding to the H. pylori outer membrane protein Q (HopQ) [67-69]. HopQ has been shown to bind with surface-exposed CEACAM receptors on host cells, which brings the T4SS-pilus to the optimal position and distance that allows for efficient CagA delivery into the gastric epithelial cells [69,70]. Moreover, a recent study investigated the interactions between $H$. pylori and three different types of oral epithelial cell lines (HN, CAL-27, and BHY). The results of this study confirmed that the CEACAM receptors that are not usually expressed on oral epithelial cells are important for CagA intracellular delivery [71].

After CagA is internalized into the epithelial cells, it employs at least two distinct mechanisms for the association of internalized CagA to the inner wall of the plasma membrane based on the cell polarity [44]. In polarized epithelial cells, CagA is tethered to the inner leaflet of the plasma membrane through its $\mathrm{N}$-terminal region containing the PS-binding regions (residues 1-876), whereas in nonpolarized cells, the internalized CagA is localized to the cytoplasm.

\section{Tyrosine Phosphorylation}

After its delivery into the gastric epithelial cells, the tyrosine $(\mathrm{Y})$ residue of the EPIYA motifs of CagA undergoes phosphorylation by various cellular kinases such as Csk, Src family kinases (SFKs), and c-Abl [72-74]. The tyrosine phosphorylation enables CagA to promiscuously interact with the $\mathrm{SH} 2$ domain, containing host proteins such as pro-oncogene Src homology 2 phosphatase (SHP2), PI3K, Crk, or the adaptor protein Grb2 [75-78]. This interaction perturbs their function, causing dysregulation of the various cell signaling pathways like Ras-ERK MAP kinases (Rap1 $\rightarrow$ B-Raf $\rightarrow$ Erk) and Wnt- $\beta$-signaling, leading to disturbances in the cellular physiology such as cell-cell adhesion, cellular proliferation, IL-8 expression, and cellular elongation [72,73,78]. The SHP2 phosphatase activity is essential for the full activation of the RAS-ERK signaling pathway, which is deregulated by the interaction of CagA with SHP2 [75]. The ERK signaling pathway has been found to play an essential role in the invasion and progression of several human malignant tumors including gastric cancer $[79,80]$. Recently, several studies have revealed the activation of the ERK pathway by H. pylori infection [81,82].

It was shown that SHP2 binds to the EPIYA-D motif with twofold stronger affinity than to the EPIYA-C motif, suggesting a stronger capability of CagA with the EPIYA-D motif for cellular transformations [83]. A recent study has shown the capability of another protein, SHIP2, containing the $\mathrm{SH} 2$ domain, to bind with the tyrosine-phosphorylated EPIYA-C or EPIYA-D segments of CagA. In the study, the complex formation between CagA and SHIP2 was found to tether the SHIP2 to the inner leaflet of the plasma membrane, leading to the increase in the level of membranous phosphatidylinositol 3,4-diphosphate PI(3,4)P2, which could strengthen the adherence of the H. pylori to the gastric epithelial cells. The H. pylori adhering with greater strength could enhance the CagA delivery into the host epithelial cells, thus enhancing the CagA-SHP2 complex formation and the risk for cellular transformation [84]. 


\section{CagA-Dependent Mechanisms of Pathogenicity}

Infection with cagPAI-positive H. pylori strains is considered the strongest risk factor for the development of severe gastroduodenal complications; however, the exact mechanism still remains unclear. CagA, after tyrosine phosphorylation, has been demonstrated to cause the cellular pathogenicity seen in H. pylori infection via different mechanisms (Table 1).

A recent study has demonstrated an increased migration and proliferation rate of cells transfected with CagA, suggesting its role in promoting the malignant transfection of gastric epithelial cells [85]. Several studies have found an enhanced probability of gastric carcinogenicity and an induction of the epithelial mesenchymal transition (EMT) process caused by CagA-positive H. pylori [86-88]. Several recent studies have found that the cells that undergo EMT acquire cancer stem cell (CSC) properties, which could induce the tumorigenesis property due to the ability of self-renewal and differentiation into a vast number of cells [89-94]. Bessede et al. conducted a study and suggested an essential role of CagA-positive H. pylori infection in the generation of cells with CSC properties in several gastric epithelial cell lines including AGS, MKN45, and MKN74 [95]. The induction of H. pylori CagA-mediated EMT has been suggested to be initiated via the stabilization of a protein, Snail1, which plays an essential role in carcinogenesis mainly by the reduction in glycogen synthase kinase-3 (GSK-3) activity [96]. In addition, the CagA-positive H. pylori-infected cells have been found to express higher mesenchymal markers such as CD44, vimentin, or zinc finger E-box binding homeobox 1 (ZEB1) [95]. A significantly higher expression of Yes-Associated-Protein (YAP) and TAZ (YAP paralog) has also been shown in cancerous gastric tissues with CagA-positive H. pylori infection, suggesting its possible role in transformation of epithelial cells [97]. YAP is a component of the Hippo tumor suppressor signaling pathway playing a crucial role in maintaining the proper size of an organ, tissue homeostasis, cell proliferation, and stem cell properties [98-100]. CagA-positive H. pylori infection has also been correlated with a decrease in E-cadherin, $\mathrm{N}$-cadherin, and Slug levels, which promotes the EMT process.

Gastrokine 1 (GKN1), a gastric tumor suppressor gene, is predominantly expressed in the stomach, which suppresses the carcinogenicity by reducing the cell viability by inhibiting the cell cycle progression and inducing cell apoptosis [101,102]. GKN1 inhibits the invasion and metastasis of gastric cancer cells, and the downregulated expression of GKN1 has been related to the poorer prognosis of intestinal gastric cancer, which has been demonstrated in chronic gastritis and gastric cancer tissues infected with $H$. pylori, suggesting that $H$. pylori-positive gastritis might progress to gastric cancer [103-106]. The findings of a recent study also demonstrated that the expression of GKN1 could be significantly downregulated in human gastritis and gastric cancer cells by $H$. pylori infection compared to $H$. pylori-negative gastritis cells, suggesting that its downregulation is mediated by the activation of the CagA-induced ERK pathway and AUF1 upregulation during H. pylori infection [107].

A recent study by Li et al. demonstrated that the activation of the YAP signaling pathway could be stimulated by CagA, rendering the AGS cells for tumorigenesis. This phenomenon was also supported by the fact that the activation of YAP expression could be enhanced in concert with E-cadherin suppression in H. pylori-infected chronic gastritis tissues compared to H. pylori-negative tissues [108]. Moreover, the CagA translocation-independent induction of cell pro-inflammatory response has been shown by $\mathrm{CagL}$, which can trigger the intracellular signaling pathways by RGD-dependent binding to integrins [48-50].

Apoptosis-stimulating protein of p53 2 (ASPP2), a host tumor suppressor and an important CagA target, has been found to contribute to the survival of CagA-positive H. pylori in the lumen of infected gastric organoids [109]. The interaction of CagA with ASPP2 has been shown to disrupt the cellular polarity, which is essential to form the mucosal barrier, a constituent of the first-line defense mechanism against the invading microbes. Remodeling of the whole PAR complex, including the apical, junctional, and basolateral components, is commenced by the delivery of CagA, suggesting the widespread effects on polarity complex proteins, rendering the loss of cell polarity and the EMT-like phenotype promoted by the interaction of CagA with Par1b [109]. 
A recent study demonstrated that the H. pylori virulence factor CagA could influence the Siva1 protein via increasing ubiquitination and proteasomal degradation mediated by the activation of the PI3K/Akt pathway and XIAP E3 ubiquitin ligase [110]. The data also suggested a downregulation of Siva1, causing inhibition of the apoptotic and DNA damage responses induced by H. pylori, whereas CagA was found to inhibit the apoptotic cell death promoting the survival of damaged epithelial cells that contributes to gastric tumorigenesis [110].

Although the presence of cagPAI has been suggested to play a key role in the H. pylori-mediated pathogenicity, the precise mechanism is still not understood. Recently, the expression of leucine-rich repeats and Ig-like domains 1 (Lrig1), a transmembrane protein acting as an intestinal stem/progenitor cell marker, has been found in the H. pylori cagPAI acting in a CagA- and CagE-dependent manner [111]. The findings also suggested a significant increase in Lrig1-positive cells in the premalignant lesions, such as atrophic gastritis and intestinal metaplasia in the antrum and corpus, indicating its possible contribution to the ability of $H$. pylori to cause injury and promote stomach carcinogenesis, which was not found in the normal stomach lining.

In response to a sudden temperature increase, bacterial cells promptly induce the expression of a group of proteins knows as heat-shock proteins (HSPs). The HSPs are crucial for cellular protection, survival, and adaptation to adverse environmental conditions [112]. Several studies have demonstrated the role of heat shock protein 1 (HSP1) in stabilizing the persistent infection mediated by CagA $[113,114]$. These studies have revealed the CagA-mediated downregulation of HSP1 expression in H. pylori-infected cells, and this downregulation, in turn, represses the host response, increasing the probability of $H$. pylori escape from the immune response, which enhances the infection establishment $[113,114]$. H. pylori CagA has also been found to promote cell proliferation by altering the cell cycle via regulation of Reg3, which controls the growth and development of tissues and organs [115]. It was found that Reg3 expression mediated by CagA could influence the occurrence and development of gastric carcinogenesis [116].

Caudal type homeobox 1 (CDX1) is a homeobox transcription factor that plays a crucial role in the development and maintenance of the human intestine [117]. Its activation has been reported to promote cell proliferation, invasion/migration, intestinalization of gastric epithelial cells, and stem cell-like phenotype induction, which leads to cancer development and failure of common gastric cancer chemotherapies [117]. An induction of CDX1 expression by secreted H. pylori CagA has been demonstrated in a recent study, suggesting that it plays an important role in the development of gastric carcinogenicity [118].

The presence of CSCs has been demonstrated in cancer tissues of several origins, and because of their abilities to self-renew and transform into multiple cell types, is considered to facilitate tumorigenesis [119]. Specific cell-surface markers have been implicated in the development of CSCs, and CD44 is one of the cell-surface markers with several isoforms generated by alternative splicing of its variant exons [120]. The cancer stem-like cells with CD44 variant 9, one of the isoforms that has been shown to enhance metastasis, contribute to the development and recurrence of gastric cancer and failure of cancer chemotherapies [121-125]. The CD44v9-positive cancer stem-like cells have been shown to accumulate and protect CagA from autophagic degradation after its translocation into the gastric epithelial cells, where it causes the reprogramming and de-differentiation of the fully differentiated cells into tissue stem-like precursor cells with CSC properties [95,126,127]. It has been suggested that the presence of the cells with enhanced expression of the capping actin protein of muscle Z-line $\alpha$-subunit 1 (CAPZA1) in H. pylori-infected gastric mucosa increases the risk of gastric carcinogenesis. In a recent study, an enhanced mRNA expression of CD44v9 was found, which was thought to be induced by the CAPZA1-overexpressing cells with accumulated CagA inside due to the H. pylori infection, suggesting the role of CAPZA1 overexpression in the predisposition of cells to develop into CD44v9 cell-surface marker-positive cells due to the accumulation of CagA [128]. 
Table 1. Mechanisms of CagA-mediated gastric carcinogenesis.

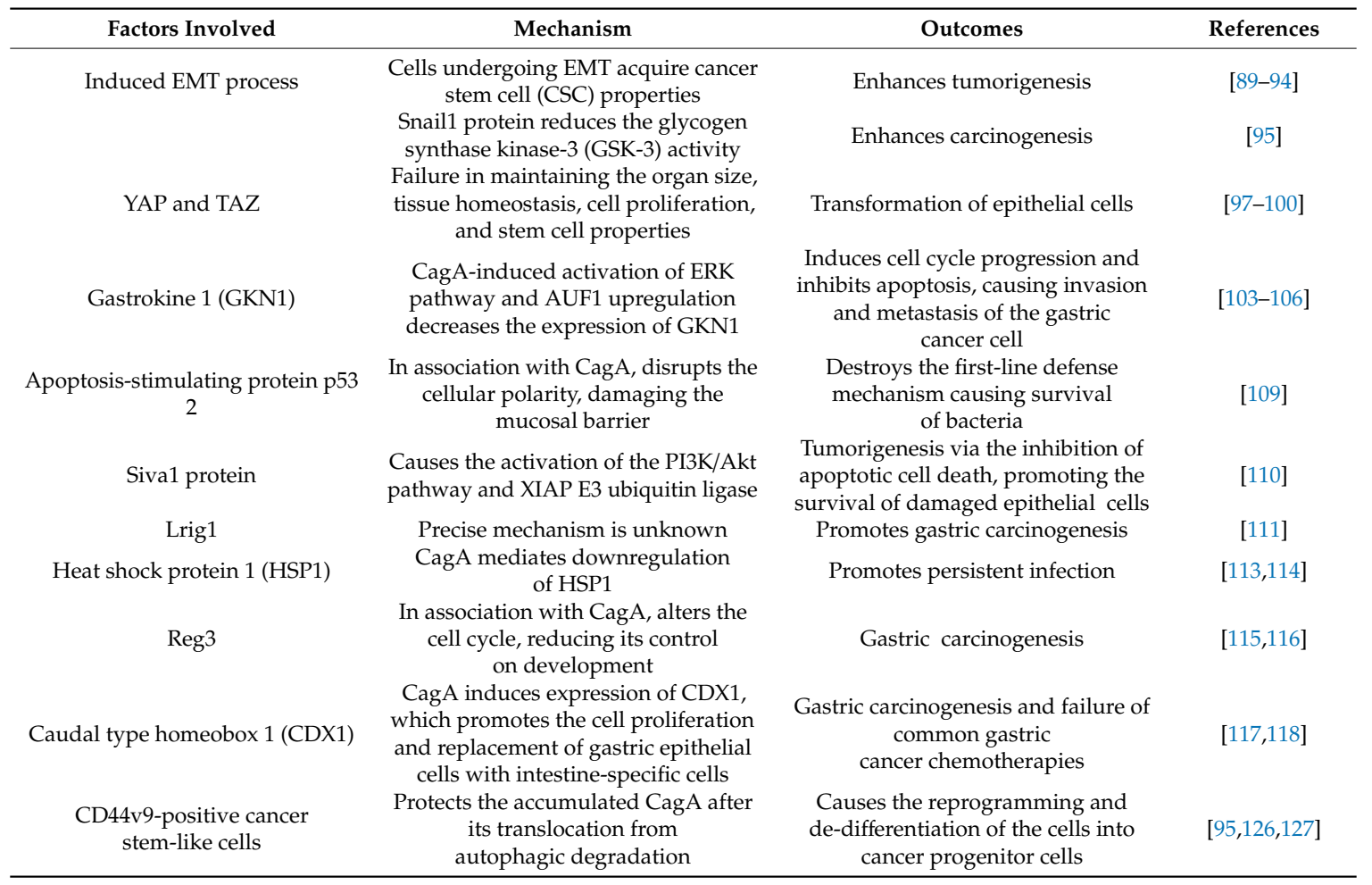

\section{Conclusions}

In this study, we indicated the importance of $H$. pylori infection and the role of effector protein CagA in gastric disease development. The strains with intact cagPAI mediating efficient CagA translocation are important for the commencement of pathogenicity. CagA, after its translocation and tyrosine phosphorylation, dysregulates the cellular signaling pathways, altering the function of several cellular proteins. Therefore, the CagA-mediated altered activity of several cellular proteins inhibits apoptosis and induces cellular proliferation.

Author Contributions: Conceptualization, Y.Y.; methodology, Y.Y. and S.A.; literature review, S.A.; original draft writing, S.A.; draft supervision, review, and editing, Y.Y.; funding acquisition, Y.Y. All authors have read and agreed to the published version of the manuscript.

Funding: This work was supported by the Ministry of Education, Culture, Sports, Science, and Technology under grant numbers 16H06279, 18KK0266, and 19H03473.

Conflicts of Interest: The authors declare no conflict of interest.

\section{References}

1. Zamani, M.; Ebrahimtabar, F.; Zamani, V.; Miller, W.H.; Alizadeh-Navaei, R.; Shokri-Shirvani, J.; Derakhshan, M.H. Systematic review with meta-analysis: The worldwide prevalence of Helicobacter pylori infection. Aliment. Pharmacol. Ther. 2018, 47, 868-876. [CrossRef] [PubMed]

2. Hooi, J.K.Y.; Lai, W.Y.; Ng, W.K.; Suen, M.M.Y.; Underwood, F.E.; Tanyingoh, D.; Malfertheiner, P.; Graham, D.Y.; Wong, V.W.S.; Wu, J.C.Y.; et al. Global Prevalence of Helicobacter pylori Infection: Systematic Review and Meta-Analysis. Gastroenterology 2017, 153, 420-429. [CrossRef] [PubMed]

3. Peleteiro, B.; Bastos, A.; Ferro, A.; Lunet, N. Prevalence of Helicobacter pylori infection worldwide: A systematic review of studies with national coverage. Dig. Dis. Sci. 2014, 59, 1698-1709. [CrossRef] [PubMed]

4. Mamishi, S.; Eshaghi, H.; Mahmoudi, S.; Bahador, A.; Hosseinpour Sadeghi, R.; Najafi, M.; Farahmand, F.; Khodadad, A.; Pourakbari, B. Intrafamilial transmission of Helicobacter pylori: Genotyping of faecal samples. Br. J. Biomed. Sci. 2016, 73, 38-43. [CrossRef] 
5. Osaki, T.; Konno, M.; Yonezawa, H.; Hojo, F.; Zaman, C.; Takahashi, M.; Fujiwara, S.; Kamiya, S. Analysis of intra-familial transmission of Helicobacter pylori in Japanese families. J. Med. Microbiol. 2015, 64 Pt 1, 67-73. [CrossRef]

6. Bui, D.; Brown, H.E.; Harris, R.B.; Oren, E. Serologic Evidence for Fecal-Oral Transmission of Helicobacter pylori. Am. J. Trop. Med. Hyg. 2016, 94, 82-88. [CrossRef]

7. Yokota, S.; Konno, M.; Fujiwara, S.; Toita, N.; Takahashi, M.; Yamamoto, S.; Ogasawara, N.; Shiraishi, T. Intrafamilial, Preferentially Mother-to-Child and Intraspousal, Helicobacter pylori Infection in Japan Determined by Multilocus Sequence Typing and Random Amplified Polymorphic DNA Fingerprinting. Helicobacter 2015, 20, 334-342. [CrossRef]

8. Jiang, J.; Chen, Y.; Shi, J.; Song, C.; Zhang, J.; Wang, K. Population attributable burden of Helicobacter pylori-related gastric cancer, coronary heart disease, and ischemic stroke in China. Eur. J. Clin. Microbiol. Infect. Dis. 2017, 36, 199-212. [CrossRef]

9. Backert, S.; Neddermann, M.; Maubach, G.; Naumann, M. Pathogenesis of Helicobacter pylori infection. Helicobacter 2016, 21, 19-25. [CrossRef]

10. Parsonnet, J.; Friedman, G.D.; Vandersteen, D.P.; Chang, Y.; Vogelman, J.H.; Orentreich, N.; Sibley, R.K. Helicobacter pylori infection and the risk of gastric carcinoma. N. Engl. J. Med. 1991, 325, 1127-1131. [CrossRef]

11. Amieva, M.; Peek, R.M., Jr. Pathobiology of Helicobacter pylori-induced gastric cancer. Gastroenterology 2016, 150, 64-78. [CrossRef] [PubMed]

12. Ansari, S.; Yamaoka, Y. Role of vacuolating cytotoxin A in Helicobacter pylori infection and its impact on gastric pathogenesis. Expert Rev. Anti-Infect. Ther. 2020. [CrossRef] [PubMed]

13. Yamaoka, Y. Mechanisms of disease: Helicobacter pylori virulence factors. Nat. Rev. Gastroenterol. Hepatol. 2010, 7, 629-641. [CrossRef] [PubMed]

14. Olbermann, P.; Josenhans, C.; Moodley, Y.; Uhr, M.; Stamer, C.; Vauterin, M.; Suerbaum, S.; Achtman, M.; Linz, B. A global overview of the genetic and functional diversity in the Helicobacter pylori cag pathogenicity island. PLoS Genet. 2010, 6, e1001069. [CrossRef]

15. Blomstergren, A.; Lundin, A.; Nilsson, C.; Engstrand, L.; Lundeberg, J. Comparative analysis of the complete cag pathogenicity island sequence in four Helicobacter pylori isolates. Gene 2004, 328, 85-93. [CrossRef]

16. Backert, S.; Tegtmeyer, N.; Fischer, W. Composition, structure and function of the Helicobacter pylori cag pathogenicity island encoded type IV secretion system. Future Microbiol. 2015, 10, 955-965. [CrossRef]

17. Chung, J.M.; Sheedlo, M.J.; Campbell, A.M.; Sawhney, N.; Frick-Cheng, A.E.; Lacy, D.B.; Cover, T.L.; Ohi, M.D. Structure of the Helicobacter pylori Cag type IV secretion system. eLife 2019, 8, e47644. [CrossRef]

18. Backert, S.; Haas, R.; Gerhard, M.; Naumann, M. The Helicobacter pylori type IV secretion system encoded by the cag pathogenicity island: Architecture, function, and signaling. Curr. Top. Microbiol. Immunol. 2017, 413, $187-220$.

19. Akopyants, N.S.; Clifton, S.W.; Kersulyte, D.; Crabtree, J.E.; Youree, B.E.; Reece, C.A.; Bukanov, N.O.; Drazek, E.S.; Roe, B.A.; Berg, D.E. Analyses of the cag pathogenicity island of Helicobacter pylori. Mol. Microbiol. 1998, 28, 37-53. [CrossRef]

20. Censini, S.; Lange, C.; Xiang, Z.; Crabtree, J.E.; Ghiara, P.; Borodovsky, M.; Rappuoli, R.; Covacci, A. Cag, a pathogenicity island of Helicobacter pylori, encodes type I- specific and disease- associated virulence factors. Proc. Natl. Acad. Sci. USA 1996, 93, 14648-14653. [CrossRef]

21. Waskito, L.A.; Miftahussurur, M.; Lusida, M.I.; Syam, A.F.; Suzuki, R.; Subsomwong, P.; Uchida, T.; Hamdan, M.; Nasronudin; Yamaoka, Y. Distribution and clinical associations of integrating conjugative elements and cag pathogenicity islands of Helicobacter pylori in Indonesia. Sci. Rep. 2018, 8, 6073. [CrossRef] [PubMed]

22. Wroblewski, L.E.; Peek, R.M., Jr. Helicobacter pylori: Pathogenic enablers-toxic relationships in the stomach. Nat. Rev. Gastroenterol. Hepatol. 2016, 13, 317-318. [CrossRef] [PubMed]

23. Cover, T.L. Helicobacter pylori diversity and gastric cancer risk. mBio 2016, 7, e01869-15. [CrossRef] [PubMed]

24. Miernyk, K.M.; Bruden, D.; Rudolph, K.M.; Hurlburt, D.A.; Sacco, F.; McMahon, B.J.; Bruce, M.G. Presence of cagPAI genes and characterization of vacA s, i and $\mathrm{m}$ regions in Helicobacter pylori isolated from Alaskans and their association with clinical pathologies. J. Med. Microbiol. 2020, 69, 218-227. [CrossRef]

25. Markovska, R.; Boyanova, L.; Yordanov, D.; Stankova, P.; Gergova, G.; Mito, I. Status of Helicobacter pylori cag pathogenicity island (cagPAI) integrity and significance of its individual genes. Infect. Genet. Evol. 2018, 59, 167-171. [CrossRef] 
26. Jiménez-Soto, L.F.; Haas, R. The CagA toxin of Helicobacter pylori: Abundant production but relatively low amount translocated. Sci. Rep. 2016, 6, 23227. [CrossRef]

27. Higashi, H.; Tsutsumi, R.; Fujita, A.; Yamazaki, S.; Asaka, M.; Azuma, T.; Hatakeyama, M. Biological activity of the Helicobacter pylori virulence factor CagA is determined by variation in the tyrosine phosphorylation sites. Proc. Natl. Acad. Sci. USA 2002, 99, 14428-14433. [CrossRef]

28. Li, Q.; Liu, J.; Gong, Y.; Yuan, Y. Association of CagA EPIYA-D or EPIYA-C phosphorylation sites with peptic ulcer and gastric cancer risks: A meta-analysis. Medicine 2017, 96, e6620. [CrossRef]

29. Zhang, X.S.; Tegtmeyer, N.; Traube, L.; Jindal, S.; Perez-Perez, G.; Sticht, H.; Backert, S.; Blaser, M.J. A specific A/T polymorphism in Western tyrosine phosphorylation B-motifs regulates Helicobacter pylori CagA epithelial cell interactions. PLoS Pathog. 2015, 11, e1004621. [CrossRef]

30. Canzian, F.; Rizzato, C.; Obazee, O.; Stein, A.; Flores-Luna, L.; Camorlinga-Ponce, M.; Mendez-Tenorio, A.; Vivas, J.; Trujillo, E.; Jang, H.; et al. Genetic polymorphisms in the cag pathogenicity island of Helicobacter pylori and risk of stomach cancer and high-grade premalignant gastric lesions. Int. J. Cancer. 2020, 1-9. [CrossRef]

31. Rizzato, C.; Torres, J.; Obazee, O.; Camorlinga-Ponce, M.; Trujillo, E.; Stein, A.; Mendez-Tenorio, A.; Bravo, M.M.; Canzian, F.; Kato, I. Variations in cag pathogenicity island genes of Helicobacter pylori from Latin American groups may influence neoplastic progression to gastric cancer. Sci. Rep. 2020, 10, 6570. [CrossRef] [PubMed]

32. Polk, D.B.; Peek, R.M., Jr. Helicobacter pylori: Gastric cancer and beyond. Nat. Rev. Cancer. 2010, 10, $403-414$. [CrossRef] [PubMed]

33. Wang, F.; Meng, W.; Wang, B.; Qiao, L. Helicobacter pylori-induced gastric inflammation and gastric cancer. Cancer Lett. 2014, 345, 196-202. [CrossRef] [PubMed]

34. Lin, W.C.; Tsai, H.F.; Kuo, S.H.; Wu, M.S.; Lin, C.W.; Hsu, P.I.; Cheng, A.L.; Hsu, P.N. Translocation of Helicobacter pylori CagA into Human B lymphocytes, the origin of mucosa-associated lymphoid tissue lymphoma. Cancer Res. 2010, 70, 5740-5748. [CrossRef] [PubMed]

35. Kuo, S.H.; Chen, L.T.; Lin, C.W.; Wu, M.S.; Hsu, P.N.; Tsai, H.J.; Chu, C.Y.; Tzeng, Y.S.; Wang, H.P.; Yeh, K.H.; et al. Detection of the Helicobacter pylori CagA protein in gastric mucosa-associated lymphoid tissue lymphoma cells: Clinical and biological significance. Blood Cancer J. 2013, 3, e125. [CrossRef] [PubMed]

36. Hashinaga, M.; Suzuki, R.; Akada, J.; Matsumoto, T.; Kido, Y.; Okimoto, T.; Kodama, M.; Murakami, K.; Yamaoka, Y. Differences in amino acid frequency in CagA and VacA sequences of Helicobacter pylori distinguish gastric cancer from gastric MALT lymphoma. Gut Pathog. 2016, 8, 54. [CrossRef]

37. Tegtmeyer, N.; Neddermann, M.; Asche, C.I.; Backert, S. Subversion of host kinases: A key network in cellular signaling hijacked by Helicobacter pylori CagA. Mol. Microbiol. 2017, 105, 358-372. [CrossRef]

38. Vaziri, F.; Peerayeh, S.N.; Alebouyeh, M.; Maghsoudi, N.; Azimzadeh, P.; Siadat, S.D.; Zali, M.R. Novel effects of Helicobacter pylori CagA on key genes of gastric cancer signal transduction: A comparative transfection study. Pathog. Dis. 2015, 73, ftu021. [CrossRef]

39. Loh, J.T.; Shaffer, C.L.; Piazuelo, M.B.; Bravo, L.E.; McClain, M.S.; Correa, P.; Cover, T.L. Analysis of cagA in Helicobacter pylori strains from Colombian populations with contrasting gastric cancer risk reveals a biomarker for disease severity. Cancer Epidemiol. Biomark. Prev. 2011, 20, 2237-2249. [CrossRef]

40. Ferreira, R.M.; Pinto-Ribeiro, I.; Wen, X.; Marcos-Pinto, R.; Dinis-Ribeiro, M.; Carneiro, F.; Figueiredo, C. Helicobacter pylori cagA promoter region sequences influence CagA expression and interleukin 8 secretion. J. Infect. Dis. 2016, 213, 669-673. [CrossRef]

41. Loh, J.T.; Lin, A.S.; Beckett, A.C.; McClain, M.S.; Cover, T.L. Role of a stem-loop structure in Helicobacter pylori cagA transcript stability. Infect. Immun. 2019, 87, e00692-18. [CrossRef] [PubMed]

42. Necchi, V.; Ricci, V.; Sommi, P.; Solcia, E. CagA Effector Protein in Helicobacter pylori-Infected Human Gastric Epithelium in Vivo: From Bacterial Core and Adhesion/Injection Clusters to Host Cell Proteasome-Rich Cytosol. Toxins 2019, 11, 618. [CrossRef] [PubMed]

43. Tegtmeyer, N.; Wessler, S.; Necchi, V.; Rohde, M.; Harrer, A.; Rau, T.T. Helicobacter pylori employs a unique basolateral type IV secretion mechanism for CagA delivery. Cell Host Microbe 2017, 22, 552-560. [CrossRef] [PubMed]

44. Murata-Kamiya, N.; Kikuchi, K.; Hayashi, T.; Higashi, H.; Hatakeyama, M. Helicobacter pylori Exploits Host Membrane Phosphatidylserine for Delivery, Localization, and Pathophysiological Action of the CagA Oncoprotein. Cell Host Microbe 2010, 7, 399-411. [CrossRef] [PubMed] 
45. Kumar, N.; Shariq, M.; Kumar, A.; Kumari, R.; Subbarao, N.; Tyagi, R.K.; Mukhopadhyay, G. Analyzing the role of $\mathrm{CagV}$, a VirB8 homolog of the type IV secretion system of Helicobacter pylori. FEBS Open Bio 2017, 7, 915-993. [CrossRef]

46. Tegtmeyer, N.; Wessler, S.; Backert, S. Role of the cag-pathogenicity island encoded type IV secretion system in Helicobacter pylori pathogenesis. FEBS J. 2011, 278, 1190-1202. [CrossRef]

47. Conradi, J.; Tegtmeyer, N.; Wozna, M.; Wissbrock, M.; Michalek, C.; Gagell, C.; Cover, T.L.; Frank, R.; Sewald, N.; Backert, S. An RGD helper sequence in CagL of Helicobacter pylori assists in interactions with integrins and injection of CagA. Front. Cell. Infect. Microbiol. 2012, 2, 70. [CrossRef]

48. Gorrell, R.J.; Guan, J.; Xin, Y.; Tafreshi, M.A.; Hutton, M.L.; McGuckin, M.A.; Ferrero, R.L.; Kwok, T. A novel NOD1- and CagA-independent pathway of interleukin-8 induction mediated by the Helicobacter pylori type IV secretion system. Cell. Microbiol. 2013, 15, 554-570. [CrossRef]

49. Saha, A.; Backert, S.; Hammond, C.E.; Gooz, M.; Smolka, A.J. Helicobacter pylori CagL activates ADAM17 to induce repression of the gastric H, K-ATPase alpha subunit. Gastroenterology 2010, 139, 239-248. [CrossRef]

50. Tegtmeyer, N.; Hartig, R.; Delahay, R.M.; Rohde, M.; Brandt, S.; Conradi, J.; Takahashi, S.; Smolka, A.J.; Sewald, N.; Backert, S. A small fibronectin-mimicking protein from bacteria induces cell spreading and focal adhesion formation. J. Biol. Chem. 2010, 285, 23515-23526. [CrossRef]

51. Tafreshi, M.; Zwickel, N.; Gorrell, R.J.; Kwok, T. Preservation of Helicobacter pylori CagA translocation and host cell pro-inflammatory responses in the face of CagL hyper-variability at amino acid residues 58/59. PLoS ONE 2015, 10, e0133531. [CrossRef] [PubMed]

52. Gorrell, R.J.; Zwickel, N.; Reynolds, J.; Bulach, D.; Kwok, T. Helicobacter pylori CagL hypervariable motif: A global analysis of geographical diversity and association with gastric cancer. J. Infect. Dis. 2016, 213, 1927-1931. [CrossRef] [PubMed]

53. Román Roman, A.; Martínez Santos, V.I.; Castañón Sánchez, C.A.; Albañil Muñoz, A.J.; Mendoza, P.G.; Soto Flores, D.G.; Martínez Carrillo, D.N.; Tilapa, G.F. CagL polymorphisms D58/K59 are predominant in Helicobacter pylori strains isolated from Mexican patients with chronic gastritis. Gut Pathog. 2019, 11, 5. [CrossRef] [PubMed]

54. Yadegar, A.; Mohabati Mobarez, A.; Zali, M.R. Genetic diversity and amino acid sequence polymorphism in Helicobacter pylori CagL hypervariable motif and its association with virulence markers and gastroduodenal diseases. Cancer Med. 2019, 8, 1619-1632. [CrossRef]

55. McClain, M.S.; Duncan, S.S.; Gaddy, J.A.; Cover, T.L. Control of gene expression in Helicobacter pylori using the Tet repressor. J. Microbiol. Methods 2013, 95, 336-341. [CrossRef]

56. Johnson, E.M.; Gaddy, J.A.; Voss, B.J.; Hennig, E.E.; Cover, T.L. Genes required for assembly of pili associated with the Helicobacter pylori cag type IV secretion system. Infect. Immun. 2014, 82, 3457-3470. [CrossRef]

57. Fischer, W.; Puls, J.; Buhrdorf, R.; Gebert, B.; Odenbreit, S.; Haas, R. Systematic mutagenesis of the Helicobacter pylori cag pathogenicity island: Essential genes for CagA translocation in host cells and induction of interleukin-8. Mol. Microbiol. 2001, 42, 1337-1348. [CrossRef]

58. Frick-Cheng, A.E.; Pyburn, T.M.; Voss, B.J.; McDonald, W.H.; Ohi, M.D.; Cover, T.L. Molecular and Structural Analysis of the Helicobacter pylori cag Type IV Secretion System Core Complex. mBio 2016, 7, e02001-e02015. [CrossRef]

59. McClain, M.S.; Voss, B.J.; Cover, T.L. Lipoprotein processing and sorting in Helicobacter pylori. mBio 2020, 11, e00911-00920. [CrossRef]

60. Barrozo, R.M.; Cooke, C.L.; Hansen, L.M.; Lam, A.M.; Gaddy, J.A.; Johnson, E.M.; Cariaga, T.A.; Suarez, G.; Peek, R.M., Jr.; Cover, T.L.; et al. Functional plasticity in the type IV secretion system of Helicobacter pylori. PLoS Pathog. 2013, 9, e1003189.

61. Suarez, G.; Romero-Gallo, J.; Sierra, J.C.; Piazuelo, M.B.; Krishna, U.S.; Gomez, M.A.; Wilson, K.T.; Peek, R.M., Jr. Genetic manipulation of Helicobacter pylori virulence function by host carcinogenic phenotypes. Cancer Res. 2017, 77, 2401-2412. [CrossRef] [PubMed]

62. Skoog, E.C.; Morikis, V.A.; Martin, M.E.; Foster, G.A.; Cai, L.P.; Hansen, L.M.; Li, B.; Gaddy, J.A.; Simon, S.I.; Solnick, J.V. CagY-dependent regulation of type IV secretion in Helicobacter pylori is associated with alterations in integrin binding. $m$ Bio 2018, 9, e00717-e00718. [CrossRef] [PubMed]

63. Sierra, J.C.; Suarez, G.; Piazuelo, M.B.; Luis, P.B.; Baker, D.R.; Romero-Gallo, J.; Barry, D.P.; Schneider, C.; Morgan, D.R.; Peek, R.M., Jr.; et al. $\alpha$-Difluoromethylornithine reduces gastric carcinogenesis by causing mutations in Helicobacter pylori cagY. Proc. Natl. Acad. Sci. USA 2019, 116, 5077-5085. [CrossRef] 
64. Barrozo, R.M.; Hansen, L.M.; Lam, A.M.; Skoog, E.C.; Martin, M.E.; Cai, L.P.; Lin, Y.; Latoscha, A.; Suerbaum, S.; Canfield, D.R. CagY is an Immune-Sensitive Regulator of the Helicobacter pylori Type IV Secretion System. Gastroenterology 2016, 151, 1164-1175. [CrossRef]

65. Wang, X.; Ling, F.; Wang, H.; Yu, M.; Zhu, H.; Chen, C.; Qian, J.; Liu, C.; Zhang, Y.; Shao, S. The Helicobacter pylori Cag pathogenicity island protein Cag1 is associated with the function of T4SS. Curr. Microbiol. 2016, 73, 22-30. [CrossRef] [PubMed]

66. Yao, Y.; Shen, Y.; Zhu, L.; Ni, Y.; Wang, H.; Shao, S. Preliminary study and bioinformatics analysis on the potential role of CagQ in type IV secretion system of H. pylori. Microb. Pathog. 2018, 116, 1-7. [CrossRef]

67. Javaheri, A.; Kruse, T.; Moonens, K.; Mejias-Luque, R.; Debraekeleer, A.; Asche, C.I.; Tegtmeyer, N.; Kalali, B.; Bach, N.C.; Sieber, S.A.; et al. Helicobacter pylori adhesin HopQ engages in a virulence-enhancing interaction with human CEACAMs. Nat. Microbiol. 2016, 2, 16189. [CrossRef]

68. Koniger, V.; Holsten, L.; Harrison, U.; Busch, B.; Loell, E.; Zhao, Q.; Bonsor, D.A.; Roth, A.; Kengmo-Tchoupa, A.; Smith, S.I.; et al. Helicobacter pylori exploits human CEACAMs via HopQ for adherence and translocation of CagA. Nat. Microbiol. 2016, 2, 16188. [CrossRef]

69. Zhao, Q.; Busch, B.; Jimenez-Soto, L.F.; Ishikawa-Ankerhold, H.; Massberg, S.; Terradot, L.; Fischer, W.; Haas, R. Integrin but not CEACAM receptors are dispensable for Helicobacter pylori CagA translocation. PLoS Pathog. 2018, 14, e1007359. [CrossRef]

70. Tegtmeyer, N.; Harrer, A.; Schmitt, V.; Singer, B.B.; Backert, S. Expression of CEACAM1 or CEACAM5 in AZ-521 cells restores the type IV secretion deficiency for translocation of CagA by Helicobacter pylori. Cell Microbiol. 2019, 21, e12965. [CrossRef]

71. Tegtmeyer, N.; Ghete, T.D.; Schmitt, V.; Remmerbach, T.; Cortes, M.C.C.; Bondoc, E.M.; Graf, H.L.; Singer, B.B.; Hirsch, C.; Backert, S. Type IV secretion of Helicobacter pylori CagA into oral epithelial cells is prevented by the absence of CEACAM receptor expression. Gut Pathog. 2020, 12, 25. [CrossRef] [PubMed]

72. Mueller, D.; Tegtmeyer, N.; Brandt, S.; Yamaoka, Y.; Poire, E.D.; Sgouras, D.; Wessler, S.; Torres, J.; Smolka, A.; Backert, S. c-Src and c-Abl kinases control hierarchic phosphorylation and function of the CagA effector protein in Western and East Asian Helicobacter pylori strains. J. Clin. Investig. 2012, 122, 1553-1566. [CrossRef] [PubMed]

73. Zanotti, G.; Cendron, L. Structural and functional aspects of the Helicobacter pylori secretome. World J. Gastroenterol. 2014, 20, 1402-1423. [CrossRef] [PubMed]

74. Khatri, A.; Wang, J.; Pendergast, A.M. Multifunctional Abl kinases in health and disease. J. Cell Sci. 2016, 129, 9-16. [CrossRef] [PubMed]

75. Higashi, H.; Tsutsumi, R.; Muto, S.; Sugiyama, T.; Azuma, T.; Asaka, M.; Hatakeyama, M. SHP-2 tyrosine phosphatase as an intracellular target of Helicobacter pylori CagA protein. Science 2002, 295, 683-686. [CrossRef] [PubMed]

76. Mimuro, H.; Suzuki, T.; Tanaka, J.; Asahi, M.; Haas, R.; Sasakawa, C. Grb2 is a key mediator of Helicobacter pylori CagA protein activities. Mol. Cell 2002, 10, 745-755. [CrossRef]

77. Hatakeyama, M. Anthropological and clinical implications for the structural diversity of the Helicobacter pylori CagA oncoprotein. Cancer Sci. 2011, 102, 36-43. [CrossRef]

78. Hatakeyama, M. Helicobacter pylori CagA and gastric cancer: A paradigm for hit-and-run carcinogenesis. Cell Host Microbe 2014, 15, 306-316. [CrossRef]

79. Asati, V.; Mahapatra, D.K.; Bharti, S.K. PI3K/Akt/mTOR and Ras/Raf/MEK/ERK signaling pathways inhibitors as anticancer agents: Structural and pharmacological perspectives. Eur. J. Med. Chem. 2016, 15, 314-341. [CrossRef]

80. Wei, L.; Li, Y.; Suo, Z. TSPAN8 promotes gastric cancer growth and metastasis via ERK MAPK pathway. Int. J. Clin. Exp. Med. 2015, 8, 8599-8607.

81. Servetas, S.L.; Bridge, D.R.; Merrell, D.S. Molecular mechanisms of gastric cancer initiation and progression by Helicobacter pylori. Curr. Opin. Infect. Dis. 2016, 29, 304-310. [CrossRef] [PubMed]

82. Costa, A.M.; Ferreira, R.M.; Pinto-Ribeiro, I.; Sougleri, I.S.; Oliveira, M.J.; Carreto, L.; Santos, M.A.; Sgouras, D.N.; Carneiro, F.; Leite, M.; et al. Helicobacter pylori activates matrix metalloproteinase 10 in gastric epithelial cells via EGFR and ERK-mediated pathways. J. Infect. Dis. 2016, 213, 1767-1776. [CrossRef] [PubMed] 
83. Hayashi, T.; Senda, M.; Suzuki, N.; Nishikawa, H.; Ben, C.; Tang, C.; Nagase, L.; Inoue, K.; Senda, T.; Hatakeyama, M. Differential Mechanisms for SHP2 binding and activation are exploited by geographically distinct Helicobacter pylori CagA Oncoproteins. Cell Rep. 2017, 20, 2876-2890. [CrossRef]

84. Fujii, Y.; Murata-Kamiya, N.; Hatakeyama, M. Helicobacter pylori CagA oncoprotein interacts with SHIP2 to increase its delivery into gastric epithelial cells. Cancer Sci. 2020, 111, 1596-1606. [CrossRef] [PubMed]

85. Ou, Y.; Ren, H.; Zhao, R.; Song, L.; Liu, Z.; Xu, W.; Liu, Y.; Wang, S. Helicobacter pylori CagA promotes the malignant transformation of gastric mucosal epithelial cells through the dysregulation of the miR-155/KLF4 signaling pathway. Mol. Carcinogenes. 2019, 58, 1427-1437. [CrossRef]

86. Naumann, M.; Sokolova, O.; Tegtmeyer, N.; Backert, S. Helicobacter pylori: A Paradigm Pathogen for Subverting Host Cell Signal Transmission. Trends Microbiol. 2017, 25, 316-328. [CrossRef]

87. Noto, J.M.; Zackular, J.P.; Varga, M.G.; Delgado, A.; Romero-gallo, J.; Scholz, M.B. Crossm Modification of the Gastric Mucosal Microbiota by a Strain-Specific Helicobacter pylori Oncoprotein and Carcinogenic. mBio 2019, 10, e00955-19. [CrossRef]

88. Oliveira, M.J.; Costa, A.M.; Costa, A.C.; Ferreira, R.M.; Sampaio, P.; Machado, J.C. CagA Associates with c-Met, E-Cadherin, andp120-Catenin in a Multiproteic Complex that Suppresses Helicobacter pylori-Induced Cell-Invasive Phenotype. J. Infect. Dis. 2009, 200, 745-755. [CrossRef]

89. Lee, S.Y.; Ju, M.K.; Jeon, H.M.; Lee, Y.J.; Kim, C.H.; Park, H.G.; Han, S.I.; Kang, H.S. Oncogenic Metabolism Acts as a Prerequisite Step for Induction of Cancer Metastasis and Cancer Stem Cell Phenotype. Oxidative Med. Cell. Longev. 2018, 2018, 1-28. [CrossRef]

90. Dongre, A.; Weinberg, R.A. New insights into the mechanisms of epithelial-Mesenchymal transition and implications for cancer. Nat. Rev. Mol. Cell Biol. 2018, 20, 69-84. [CrossRef]

91. Park, A.H.; Shin, J.E.; Park, H.W. The role of Hippo Pathway in Cancer Stem Cell Biology. Mol. Cells 2018, 41, 83-92. [PubMed]

92. Singh, M.; Yelle, N.; Venugopal, C.; Singh, S.K. EMT: Mechanisms and therapeutic implications. Pharmacol. Ther. 2018, 182, 80-94. [CrossRef] [PubMed]

93. Toh, T.B.; Lim, J.J.; Chow, E.K.H. Epigenetics in cancer stem cells. Mol. Cancer 2017, 16, 1-20. [CrossRef] [PubMed]

94. Santos, J.C.; Carrasco-Garcia, E.; Garcia-Puga, M.; Aldaz, P.; Montes, M.; Fernandez-Reyes, M.; de Oliveira, C.C.; Lawrie, C.H.; Arauzo-Bravo, M.J.; Ribeiro, M.L.; et al. SOX9 Elevation Acts with Canonical WNT Signaling to Drive Gastric Cancer Progression. Cancer Res. 2016, 76, 6735-6746. [CrossRef] [PubMed]

95. Bessède, E.; Staedel, C.; Acuña Amador, L.A.; Nguyen, P.H.; Chambonnier, L.; Hatakeyama, M.; Belleannee, G.; Megraud, F.; Varon, C. Helicobacter pylori generates cells with cancer stem cell properties via epithelial-Mesenchymal transition-Like changes. Oncogene 2014, 33, 4123-4131. [CrossRef] [PubMed]

96. Lee, D.G.; Kim, H.S.; Lee, Y.S.; Kim, S.; Cha, S.Y.; Ota, I.; Kim, N.H.; Cha, Y.H.; Yand, D.H.; Lee, Y.; et al. Helicobacter pylori CagA promotes Snail-Mediated epithelial-Mesenchymal transition by reducing GSK-3 activity. Nat. Commun. 2014, 5, 1-13. [CrossRef]

97. Mo, J.S.; Meng, Z.; Kim, Y.C.; Park, H.W.; Hansen, C.G.; Kim, S.; Lim, D.S.; Guan, K.L. Cellular energy stress induces AMPK-mediated regulation of YAP and the Hippo pathway. Nat. Cell Biol. 2015, 17, 500-510. [CrossRef] [PubMed]

98. Koo, J.H.; Guan, K.-L. Interplay between YAP/TAZ and Metabolism. Cell Metab. 2018, 28, 196-206. [CrossRef] [PubMed]

99. Chen, Y.-A.; Lu, C.-Y.; Cheng, T.-Y.; Pan, S.-H.; Chen, H.-F.; Chang, N.-S. WW Domain-Containing Proteins YAP and TAZ in the Hippo Pathway as Key Regulators in Stemness Maintenance, Tissue Homeostasis, and Tumorigenesis. Front. Oncol. 2019, 9, 60. [CrossRef]

100. Zanconato, F.; Cordenonsi, M.; Piccolo, S. YAP/TAZ at the Roots of Cancer. Cancer Cell 2016, $29,783-803$. [CrossRef]

101. Menheniott, T.R.; Kurklu, B.; Giraud, A.S. Gastrokines: Stomach-specific proteins with putative homeostatic and tumor suppressor roles. Am. J. Physiol. Gastrointest. Liver Physiol. 2013, 304, 109-121. [CrossRef] [PubMed]

102. Yoshikawa, Y.; Mukai, H.; Hino, F.; Asada, K.; Kato, I. Isolation of two novel genes, down-regulated in gastric cancer. Jpn. J. Cancer Res. 2000, 91, 459-463. [CrossRef] [PubMed]

103. Xing, R.; Li, W.; Cui, J.; Zhang, J.; Kang, B.; Wang, Y.; Wang, Z.; Liu, S.; Lu, Y. Gastrokine 1 induces senescence through $\mathrm{p} 16 / \mathrm{Rb}$ pathway activation in gastric cancer cells. Gut 2012, 61, 43-52. [CrossRef] [PubMed] 
104. Yoon, J.H.; Kang, Y.H.; Choi, Y.J.; Nam, S.W.; Lee, J.Y.; Lee, Y.S.; Park, W.S. Gastrokine 1 functions as a tumor suppressor by inhibition of epithelial-mesenchymal transition in gastric cancers. J. Cancer Res. Clin. Oncol. 2011, 137, 1697-1704. [CrossRef] [PubMed]

105. Yoon, J.H.; Choi, W.S.; Kim, O.; Park, W.S. The role of gastrokine 1 in gastric cancer. J. Gastric Cancer 2014, 14, 147-155. [CrossRef]

106. Moss, S.F.; Lee, J.W.; Sabo, E.; Rubin, A.K.; Rommel, J.; Westley, B.R.; May, F.E.B.; Gao, J.; Meitner, P.A.; Tavares, R.; et al. Decreased expression of gastrokine 1 and the trefoil factor interacting protein TFIZ1/GKN2 in gastric cancer: Influence of tumor histology and relationship to prognosis. Clin. Cancer Res. 2008, 14, 4161-4167. [CrossRef]

107. Guo, Y.; Zhang, T.; Shi, Y.; Zhang, J.; Li, M.; Zhang, J.; Chen, X.; Ding, S. Helicobacter pylori inhibits GKN1 expression via the CagA/pERK/AUF1 pathway. Helicobacter 2020, 25, e12665. [CrossRef]

108. Li, N.; Feng, Y.; Hu, Y.; He, C.; Xie, C.; Ouyang, Y.; Artim, S.C.; Huang, D.; Zhu, Y.; Luo, Z.; et al. Helicobacter pylori CagA promotes epithelial mesenchymal transition in gastric carcinogenesis via triggering oncogenic YAP pathway. J. Exp. Clin. Cancer Res. 2018, 37, 280. [CrossRef]

109. Buti, L.; Ruiz-Puig, C.; Sangberg, D.; Leissing, T.M.; Brewer, R.C.; Owen, R.P.; Sgromo, B.; Royer, C.; Ebner, D.; $\mathrm{Lu}, \mathrm{X}$. CagA-ASPP2 complex mediates loss of cell polarity and favors $H$. pylori colonization of human gastric organoids. Proc. Natl. Acad. Sci. USA 2020, 117, 2645-2655. [CrossRef]

110. Palrasu, M.; Zaika, E.; El-Rifai, W.; Garcia-Buitrago, M.; Piazuelo, M.B.; Wilson, K.T.; Peek, R.M., Jr.; Zaika, A.I. Bacterial CagA protein compromises tumor suppressor mechanisms in gastric epithelial cells. J. Clin. Investig. 2020, 130, 2422-2434. [CrossRef]

111. Wroblewski, L.E.; Choi, E.; Petersen, C.; Delgado, A.G.; Piazuelo, M.B.; Romero-Gallo, J.; Lantz, T.L.; Zavros, Y.; Coffey, R.J.; Goldenring, J.R.; et al. Targeted mobilization of Lrig1 gastric epithelial stem cell populations by a carcinogenic Helicobacter pylori type IV secretion system. Proc. Natl. Acad. Sci. USA 2019, 116, 19652-19658. [CrossRef] [PubMed]

112. Roncarati, D.; Scarlato, V. The Interplay between Two Transcriptional Repressors and Chaperones Orchestrates Helicobacter pylori Heat-Shock Response. Int. J. Mol. Sci. 2018, 19, 1702. [CrossRef] [PubMed]

113. Lang, B.J.; Gorrell, R.J.; Tafreshi, M.; Hatakeyama, M.; Kwok, T.; Price, J.T. The Helicobacter pylori cytotoxin CagA is essential for suppressing host heat shock protein expression. Cell Stress Chaperones 2016, 21, 523-533. [CrossRef] [PubMed]

114. Axsen, W.S.; Styer, C.M.; Solnick, J.V. Inhibition of heat shock protein expression by Helicobacter pylori. Microb. Pathog. 2009, 47, 231-236. [CrossRef] [PubMed]

115. Liu, B.; Li, X.; Sun, F.; Tong, X.; Bai, Y.; Jin, K.; Liu, L.; Dai, F.; Li, N. HP-CagA+ Regulates the Expression of CDK4/CyclinD1 via reg3 to Change Cell Cycle and Promote Cell Proliferation. Int. J. Mol. Sci. 2020, 21, 224. [CrossRef]

116. Waldum, H.L.; Qvigstad, G.; Sandvik, A.K. Reg protein in gastric cancer tumour cells. FEBS Lett. 2003, 553, 464-465. [CrossRef]

117. Grainger, S.; Hryniuk, A.; Lohnes, D. Cdx1 and Cdx2 exhibit transcriptional specificity in the intestine. PLoS ONE 2013, 8, e54757. [CrossRef]

118. Choi, S.I.; Yoon, C.; Park, M.R.; Lee, D.; Kook, M.C.; Lin, J.X.; Kang, J.H.; Ashktorab, H.; Smoot, D.T.; Yoon, S.S.; et al. CDX1 expression induced by CagA-expressing Helicobacter pylori promotes gastric tumorigenesis. Mol. Cancer Res. 2019, 17, 2169-2183. [CrossRef]

119. Reya, T.; Morrison, S.J.; Clarke, M.F.; Weissman, I.L. Stem cells, cancer, and cancer stem cells. Nature 2001, 414, 105-111. [CrossRef]

120. Dalerba, P.; Dylla, S.J.; Park, I.K.; Liu, R.; Wang, X.; Cho, R.W.; Hoey, T.; Gurney, A.; Huang, E.H.; Simeone, D.M.; et al. Phenotypic characterization of human colorectal cancer stem cells. Proc. Natl. Acad. Sci. USA 2007, 104, 10158-10163. [CrossRef]

121. Ishimoto, T.; Nagano, O.; Yae, T.; Tamada, M.; Motohara, T.; Oshima, H.; Oshima, M.; Ikeda, T.; Asaba, R.; Yagi, H.; et al. CD44 variant regulates redox status in cancer cells by stabilizing the XCT subunit of system xc(-) and thereby promotes tumor growth. Cancer Cell 2011, 19, 387-400. [CrossRef] [PubMed]

122. Miyoshi, S.; Tsugawa, H.; Matsuzaki, J.; Hirata, K.; Mori, H.; Saya, H.; Kanai, T.; Suzuki, H. Inhibiting xCT improves 5-fluorouracil resistance of gastric cancer induced by CD44 variant 9 expression. Anticancer Res. 2018, 38, 6163-6170. [CrossRef] [PubMed] 
123. Hirata, K.; Suzuki, H.; Imaeda, H.; Matsuzaki, J.; Tsugawa, H.; Nagano, O.; Asakura, K.; Saya, H.; Hibi, T. CD44 variant 9 expression in primary early gastric cancer as a predictive marker for recurrence. Br. J. Cancer 2013, 109, 379-386. [CrossRef] [PubMed]

124. Kodama, H.; Murata, S.; Ishida, M.; Yamamoto, H.; Yamaguchi, T.; Kaida, S.; Miyake, T.; Takebayashi, K.; Kushima, R.; Tani, M. Prognostic impact of CD44-positive cancer stem-like cells at the invasive front of gastric cancer. Br. J. Cancer 2017, 116, 186-194. [CrossRef] [PubMed]

125. Yamakawa, Y.; Kusuhara, M.; Terashima, M.; Kinugasa, Y.; Sugino, T.; Abe, M.; Mochizuki, T.; Hatakeyama, K.; Kami, K.; Yamaguchi, K. CD44 variant 9 expression as a predictor for gastric cancer recurrence: Immunohistochemical and metabolomic analysis of surgically resected tissues. Biomed. Res. 2017, 38, 41-52. [CrossRef] [PubMed]

126. Bagnoli, F.; Buti, L.; Tompkins, L.; Covacci, A.; Amieva, M.R. Helicobacter pylori CagA induces a transition from polarized to invasive phenotypes in MDCK cells. Proc. Natl. Acad. Sci. USA 2005, 102, 16339-16344. [CrossRef]

127. Tsugawa, H.; Suzuki, H.; Saya, H.; Hatakeyama, M.; Hirayama, T.; Hirata, K.; Nagano, O.; Matsuzaki, J.; Hibi, T. Reactive oxygen species-induced autophagic degradation of Helicobacter pylori CagA is specifically suppressed in cancer stem-like cells. Cell Host Microbe 2012, 12, 764-777. [CrossRef]

128. Tsugawa, H.; Kato, C.; Mori, H.; Matsuzaki, J.; Kameyama, K.; Saya, H.; Hatakeyama, M.; Suematsu, M.; Suzuki, H. Cancer stem-cell marker CD44v9-positive cells arise from Helicobacter pylori- infected CAPZA1-overexpressing cells. Cell Mol. Gastroenterol. Hepatol. 2019, 8, 319-334. [CrossRef]

(C) 2020 by the authors. Licensee MDPI, Basel, Switzerland. This article is an open access article distributed under the terms and conditions of the Creative Commons Attribution (CC BY) license (http://creativecommons.org/licenses/by/4.0/). 